\title{
Did We Need Low Energy Campus Mosque?
}

\author{
Bangun IR Harsritanto, ${ }^{*}$, Satrio Nugroho ${ }^{1}$, Muhammad Denton Alif Ghafirin ${ }^{1}$, and Aditya Rio Prabowo ${ }^{2}$ \\ ${ }^{1}$ Architecture Department, Faculty of Engineering, Diponegoro University, Semarang - Indonesia \\ ${ }^{2}$ Department of Mechanical Engineering, Faculty of Engineering, Universitas Sebelas Maret, Surakarta - Indonesia
}

\begin{abstract}
Campus mosque is the center of Moslem Civitas Academica's in worshiping/salah. Undip as one of the biggest university had build low energy campus mosque on Tembalang. However, the built mosque might not provide the people demanded during the worshiping. This study was performed by literature review (ASHRAE and tropical building Physic), direct thermal investigation (air temperature, humidity and speed), and worshiper's satisfaction questionaires. The results were contradiction between worshipper opinions and thermal energy tests.
\end{abstract}

Keywords: Campus mosque; Low Energy; Thermal Comfort; Worship.

\section{Introduction}

Mosque derived from masjid (place of submission) [1]. Mosque is only a place to perform salah, but also another worshiping activity such as dzikr, Al Quran tadarus and recitation, religious school, etc [2]. The mosque itself become main part of Islamic activity which facilitated by high-quality architecture building [3]

Mosque must provide spaces for better-worshiping quality. Undip Mosque has two floors with wide-span roof structure to support low energy system. The wide and high roof structure is tropical architecture character in low energy consumption response [4]. Low energy building also can be supported by the sun shading $\operatorname{roof}($ tritisan) and outside corridor (emper) [5]. Undip mosque has established both of the roof types and extended spaces as the low energy building strategy especially in heat ventilating and air conditioning (HVAC).

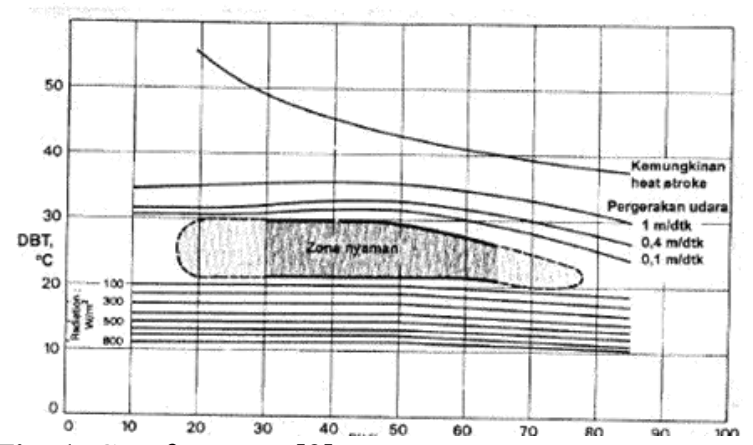

Fig. 1. Comfort zone [9]

Thermal comfort is a condition accepted by users in certain spaces to perform their activities. The tropical area has to fix thermal condition so every tropic building design shall be maintained their thermal comfort. [6-7].
Standard on ASHRAE tropical area's thermal comfort, it can be reached by effective temperature of $23^{\circ} \mathrm{C}-27^{\circ} \mathrm{C}$, humidity of $30 \%-60 \%$, and air velocity of $0,2 \mathrm{~m} / \mathrm{s}$ [8]. However domestic research indicated that tropical wet area has received the thermal comfort on limit temperature (T) of $24^{\circ} \mathrm{C}<\mathrm{T}<26^{\circ} \mathrm{C}$, limit Relative Humidity (RH) $40 \%<\mathrm{RH}<60 \%$, limit air velocity (V) of $0,6 \mathrm{~m} / \mathrm{s}<\mathrm{V}<1,5 \mathrm{~m} / \mathrm{s}$ by using a layer casual shirts (see figure 1) [9].

This research performed literature review (ASHRAE and Satwiko's tropical building Physic), direct thermal investigation (air temperature, humidity and speed), and worshiper's satisfaction questionaires. The study purposed to investigate building performance and worshipper's thermal comfort. The results were worshipper opinions and numerical thermal condition tests combined to answer "DID WE NEED LOW ENERGY CAMPUS MOSQUE?"

\section{Methods}

The Evaluation methods were described as three big scenarios [10]. The trio of literature reviews, direct investigations or site observation and questionaires control.

1. Literature reviews to establish the fundamental research tropical building theory

2. The direct investigations were performed to obtain: air temperature, humidity, and air velocities.

3. Questionaires to get user's satisfaction on the thermal performance of campus mosque

From the three main methods, later on, the variables can be described as :

- Independent variabels: air temperature, relative humidity and air velocities

- Dependent variables: user thermal comfort

\footnotetext{
* Corresponding author: bangunirh@arsitektur.undip.ac.id
} 
The questionaires were given to campus mosques visitor who commonly is healthy students in 18-24 years old range. So they are more strong in wide thermal conditions [11] The questionaires were about : 3 comfort zones inside the mosque and 3 on outside corridors.

The direct investigations were performed during on hot period of 19 and 20 march 2018 at dzuhur time of 12.00WIB and Ashar of 15.00WIB [12] on a spot of six zones (see Fig. 2). The thermal investigations were using well-calibrated tools of digital thermo-hygrometer and digital anemometer [13]. The thermo-hygrometer was used to gain air temperature and relative humidities data (see Fig. 3). The Digital anemometer was functioned to estimate the air velocity during certain periods (see Fig. 4).

During the direct investigation, all the rear openings between zone 3 and 5 were closed and the air ventilation are coming from the side openings between zone 4 and 6. (see Fig. 2)

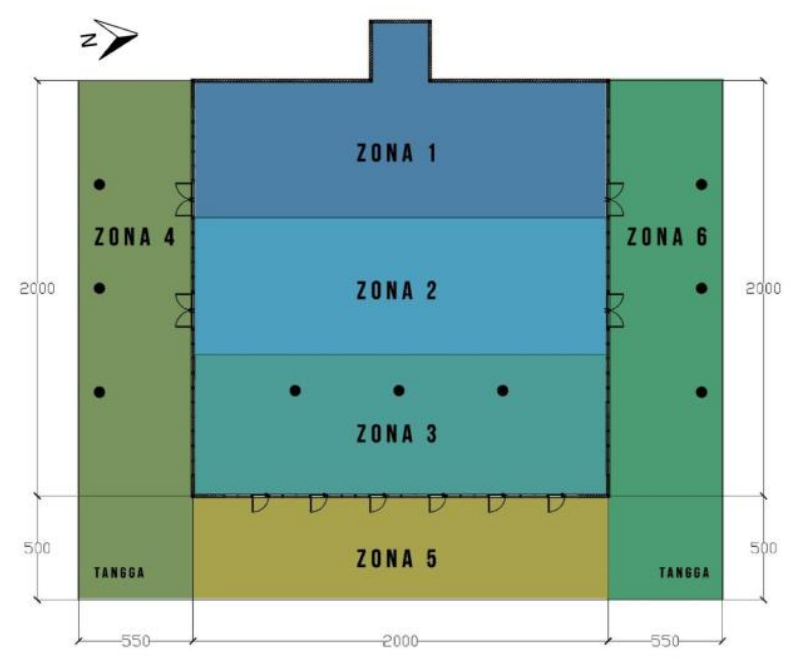

Fig. 2. Investigation zones

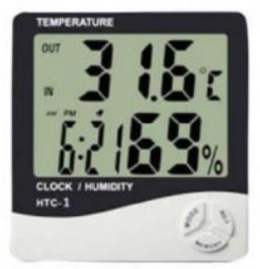

Fig. 3. Thermo-hygrometer

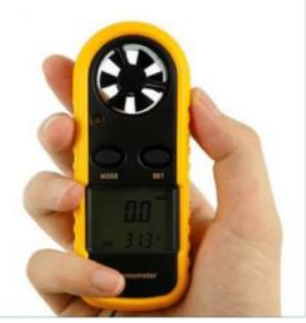

Fig. 4. Anemometer Digital

\section{Discussion}

The room temperature is a result from internal part of body heat, the burning of machines/tools ,and external part of solar heat, window, and walls conduction, heatwave convections and ultra violet-infrared radiation. In this case the internal part roled most of the room temperature conditions [8].
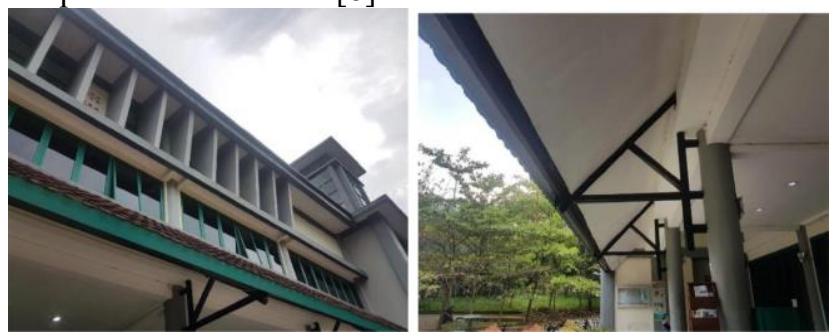

Fig. 5. Low Energy strategy

The direct investigation results were shown that average room temperature is $30^{\circ} \mathrm{C}$ with $71 \%$ humidity and $0.7 \mathrm{~m} / \mathrm{s}$ air velocity. The thermal comfort $[8,9]$ is achieved at air temperatures $23.5^{\circ} \mathrm{C}-26.5^{\circ} \mathrm{C}$, relative humidity $35 \%-75 \%$, and air $0.4 \mathrm{~m} / \mathrm{s}-1.15 \mathrm{~m} / \mathrm{s}$ (see table 1). From these situations, author can be assumed that the low energy design concept which being targeted on this mosque had failed. The certain criteria of thermal comfort were unaccomplished by the design elements such as roof extension and high ventilation (see figure 5). The further discussion of low energy consumption would be focused on user preference rather than passive design criteria.

Table 1. Direct investigation results

\begin{tabular}{|c|c|c|c|c|c|c|c|c|}
\hline \multirow[b]{3}{*}{ items } & \multicolumn{6}{|c|}{ The zone } & \multicolumn{2}{|c|}{ reference } \\
\hline & \multicolumn{3}{|c|}{ Indoor zone } & \multicolumn{3}{|c|}{ Extention zone } & \multirow[b]{2}{*}{ Ashrae } & \multirow[b]{2}{*}{ Building } \\
\hline & 1 & 2 & 3 & 4 & 5 & & & \\
\hline Temp $\left({ }^{\circ} \mathrm{C}\right)$ & 29.3 & 29.5 & 29.7 & 28.9 & 28.6 & 28.5 & $23-27$ & $24-26$ \\
\hline Humidity(\%) & 68.5 & 67.5 & 68.0 & 73.5 & 74.5 & 73.0 & 30-90 & $40-60$ \\
\hline $\operatorname{Velocity}(\mathrm{m} / \mathrm{s})$ & 0.0 & 0.0 & 0.6 & 1.4 & 1.0 & 1.1 & $0.2-0.8$ & $0.6-1.5$ \\
\hline
\end{tabular}

The questionaire result shown that all the six-zone on the Mosque are the comfort zone for worshiping rituals. However, the statistic indicated the highest rate were zone 1, zone 2, zone 3 then outer zone such: zone 4, zone 5 and zone 6 (see table 2). The first zone and first row is the most favorite place and becomes the most comfort zone to do salah, as the effect of Prophet Muhammad's hadith [14].

Table 2. Questionnaire on mosque zone

\begin{tabular}{|l|l|c|c|c|l|}
\hline No. & Perform salah on position & $\mathrm{T}$ & $\mathrm{H}$ & $\mathrm{V}$ & $\%$ \\
\hline 1 & Zone 1 & 30 & 68 & 0 & 54 \\
\hline 2 & Zone 2 & 29 & 67 & 0 & 40 \\
\hline 3 & Zone 3 & 29 & 68 & 0 & 30 \\
\hline 4 & Zone 4 & 28 & 73 & 0.5 & 28 \\
\hline 5 & Zone 5 & 28 & 73 & 0.5 & 27 \\
\hline 6 & Zone 6 & 28 & 73 & 1 & 26 \\
\hline
\end{tabular}


Further notices from user opinions about the mosque are: they did not demand specific thermal criteria (shown in table 2). However, they paid attention to the air velocity (see table 3 ). Air velocities or winds made short sensations to the human body. But in tropical areas (have more stabilized temperature and humidity) brought the short sensation into more impacts in behavior since the other elements were low changes. During the measurement, the changes of $0 \mathrm{~m} / \mathrm{s}$ into $1 \mathrm{~m} / \mathrm{s}$ velocity "touch" can be felt by people compared to the $73 \%$ into $67 \%$ humidity and $30^{\prime} \mathrm{C}$ into $28^{\prime} \mathrm{C}$ of temperatures.

The "layer" of humidity and temperature is attached to the human skins/clothes every time. So the alteration in single-digit of celcius and percentage would not be sensed by people.

If we compared the number, the alteration on velocity is under one point and the humidity-temperatures are above two points. Since the layer always attached and the touch gave short sensation, the wind more demanded rather than the humidity and temperature changes.

Furthermore, the situation of zone 1 has the highest shade to the sunlight can be the main demand of worshiper comfort during days. The activity of short solitude worshiping and lumination on that zone to read al quran may bring this zone the most favorite during days (dzuhur until ashr). However, on more longer period of reading Al Quran, the worshipper prefers the outer zone of mosque. Those situation has shown that they have no attention to the failed low energy (lighting and air conditioning) consumption design from this mosque.

Table 3. Questionnaire on mosque thermal

\begin{tabular}{|l|l|l|l|l|l|l|}
\hline No. & Items & -2 & -1 & 0 & 1 & 2 \\
\hline 1 & Mosque capacities & $0 \%$ & $4 \%$ & $10 \%$ & $30 \%$ & $56 \%$ \\
\hline 2 & Openings Location & $2 \%$ & $6 \%$ & $8 \%$ & $34 \%$ & $50 \%$ \\
\hline 3 & Opening quantities & $4 \%$ & $8 \%$ & $16 \%$ & $34 \%$ & $38 \%$ \\
\hline 4 & Afternoon temperature & $0 \%$ & $10 \%$ & $20 \%$ & $34 \%$ & $36 \%$ \\
\hline 5 & Evening temperature & $0 \%$ & $2 \%$ & $34 \%$ & $32 \%$ & $32 \%$ \\
\hline 6 & Afternoon Humidity & $6 \%$ & $22 \%$ & $28 \%$ & $34 \%$ & $10 \%$ \\
\hline 7 & EveningHumidity & $3 \%$ & $24 \%$ & $24 \%$ & $40 \%$ & $6 \%$ \\
\hline 8 & Afternoon Air Velocity & $2 \%$ & $4 \%$ & $28 \%$ & $44 \%$ & $22 \%$ \\
\hline 9 & Evening Air & $2 \%$ & $6 \%$ & $30 \%$ & $48 \%$ & $14 \%$ \\
\cline { 2 - 6 } & Velocity & & & & & \\
\hline
\end{tabular}
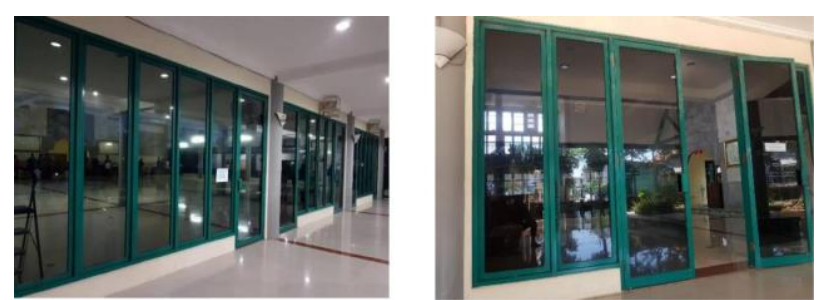

Fig. 6. Openings

Table 3 indicated that people accept all situation of physical and thermal elements on this mosque. Those conditions showed that the worshipper has no significant demand to thermal conditions. They prefer to concentrate on their ritual activities shall be facilitated by the mosque capacities with many openings on the wall (see figure 6). However during the investigation, all the openings were closed by the worshipper due to the street's noise. The dilemma of air velocity and noise also failed to be designed by the low energy concept of mosque and brought unsolved problems to the mosque itself

\section{Conclusion}

The studies concluded that the low energy consumption design was failed to meet the ASHRAE and Tropical Building Physic Standards. However, the thermal comfort of standards did not related to the user thermal comfort. The building science approach in this situation might not the priority in designing place of worshiping like mosque. The ritual activities play more role in building function rather than thermal comfort and low energy design

\section{Acknowledgement}

This research was financially supported by The Faculty of Engineering, Diponegoro University, Indonesia through Strategic Research Grant.

\section{References}

1. M. Shihab, WawasanAl-Qur'an, (2018) From : http://media.isnet.org/islam/Quraish/Wawasan/Masji d.html accesed June 2018

2. M. Ayub, Manajemen Masjid Petunjuk Praktis bagi Para Pengurus, Jakarta: Gema Insani (1996)

3. M. Faqih et al, Tipologi Arsitektur Masjid-TanpaArsitek, Lembaga Penelitian (1992)

4. G. Lippsmeier, Bangunan Tropis, Erlangga, Jakarta (1997)

5. H. Karyono, Arsitektur dan Kota Tropis Dunia Ketiga, Raja Grafindo Persada, Jakarta (2013)

6. Soegijanto, Standar Tata Cara Perancangan Konversi Energi pada Bangunan Gedung, Seminar Hemat Energi dalam Bangunan (1998)

7. A. Sekatia, B.I.R. Harsritanto, E. Setyowati, G. Hardiman, AIP Conference Proceedings 1977, 060015 (2018)

8. ASHRAE. Handbook of Fundamental Chapter 8: Physiological Principles, Comfort, and Health. ASHRAE. USA (1989)

9. P. Satwiko, Fisika Bangunan, Andi, Yogyakarta (2008)

10. BIR, Harsritanto. E3S Web of Conferences 31, 09010 (2018)

11. ASHRAE Handbook. Heating, Ventilating, and AirConditioning, Inc. ASHRAE. Atlanta (2004)

12. BMKG, Buletin Prakiraan Hujan Bulanan, Stasiun Klimatologi Semarang (2018)

13. BIR, Harsritanto, R. Widiastuti. HFS. Rusyida, Advanced Science Letters, 24, 9548-9551 (2018) 
14. A. Pratama, Keutamaan Shaf Pertama (2011) 